\title{
STATE-OF-THE-ART AND PROSPECTS OF WORLD AND REGIONAL MARKETS OF WELDING MATERIALS (Review) ${ }^{*}$
}

A.A. MAZUR, S.V. PUSTOVOJT, O.K. MAKOVETSKAYA, N.S. BROVCHENKO and V.S. PETRUK

E.O. Paton Electric Welding Institute, NASU

11 Bozhenko Str., 03680, Kiev, Ukraine. E-mail: office@paton.kiev.ua

\begin{abstract}
Electric arc welding is one of the basic technologies of an industrial economy, by means of which a significant share of GDP of industrialized countries is created. These countries are characterized by a stable development of welding production, which is defined by the growth in consumption of structural materials, emergence of new materials, technologies and equipment for welding to the market. The main structural material for manufacture of welded structures is steel, therefore, the state of the industry for its production defines mainly the dynamics of the welding production development. Economic-statistic information about the development of the world production and consumption of steel, dynamics of the world market of welding materials allows making conclusion about the increase of volumes of welding production in the world in the foreseeable future and growth of demand for the welding materials. At present the cost volume of the world market of welding materials amounts almost to a half of volume of the welding market. The growth in consumption of welding materials in the world is determined by the rates of development of the welding production in China, much more exceeding in this respect the rest countries and regions. Due to reduction in a share of manual arc welding and wider application of the semiautomatic and automatic welding the level of mechanization and automation of arc welding both in separate countries and also all over the world is continuously increased. 12 Ref., 5 Tables, 9 Figures.
\end{abstract}

$\boldsymbol{K} \boldsymbol{e} \boldsymbol{y} \boldsymbol{w} \boldsymbol{o r d} \boldsymbol{s}:$ welding, welding production, structural and welding materials, technologies, steel production, market, state-of-the-art, prospects

The electric arc welding, becoming in the XX century as one of the basic technologies of industrial economy, did not also lose its importance today. The welding is a key method of producing the permanent joints of metals and non-metals, providing the creation of a significant share of GDP of the industrialized countries [1-3]. It is impossible to imagine the present civilization without welding and other allied processes. If suddenly all the welded, brazed and other permanent joints are ruined, then the mankind will remain without the majority of machines, mechanisms and other means of production and communication, without transport, electricity, buildings and constructions, habitual household appliances, without space. And even without computers, modern electronics and other material elements of the IT-technologies it is impossible to create the information-oriented society, i.e. the society of future.

Strategies of development of national welding productions for medium-term prospects have no almost the great differences and are oriented to the solution of urgent problems, such as increase in volumes and widening the fields of application of welding and allied technologies, increase in welding efficiency at simultaneous guarantee of high quality of joints, growth of level of mechanization and automation of welding jobs, decrease in energy consumption and expenses for welding and allied technologies; widening of application of new advanced metallic, composite and non-metallic materials in welded structures and constructions.

Stable and effective progress of welding productions in the industrialized countries is based on applying of results of fundamental and applied investigations, high scientific-engineering potential, qualified labor resources and active transfer of high welding technologies and other innovations.

Hence, it results in great attention, which is paid in the whole world to the development of welding science and technology, improvement of technological processes of welding, including the fusion arc welding. In the opinion of national and foreign specialists, it will also remain as the leading method of producing permanent joints in the foreseeable future (Table 1).

Science- and engineering-intensive welding production has an inter-industry nature, and in the metal working industries and construction, this is, as a rule, a self-dependent production and

*From materials of paper presented at the VIII International Conference «Welding Consumables» (Kiev, PWI, 16-18 June, 2014).

๑ A.A. MAZUR, S.V. PUSTOVOJT, O.K. MAKOVETSKAYA, N.S. BROVCHENKO and V.S. PETRUK, 2014 
Table 1. Development of the European market of welding engineering and technologies (for the nearest 10 years)

\begin{tabular}{|l|c|c|c||}
\hline Technological sector of market & $\begin{array}{c}\text { Without } \\
\text { changes or } \\
\text { negligible } \\
\text { increment }\end{array}$ & Increment & $\begin{array}{c}\text { Significant } \\
\text { increment }\end{array}$ \\
\hline $\begin{array}{l}\text { Arc welding with consum- } \\
\text { able electrode }\end{array}$ & & $\times$ & \\
\hline $\begin{array}{l}\text { Arc welding with non-con- } \\
\text { sumable electrode }\end{array}$ & $\times$ & $\times$ & \\
\hline $\begin{array}{l}\text { Submerged arc welding } \\
\text { and electroslag welding }\end{array}$ & $\times$ & $\times$ & \\
\hline Plasma-arc welding & $\times$ & $\times$ & \\
\hline Laser welding & & $\times$ & $\times$ \\
\hline Electron beam welding & & $\times$ & $\times$ \\
\hline $\begin{array}{l}\text { Resistance spot and seam } \\
\text { welding }\end{array}$ & $\times$ & $\times$ & \\
\hline Flash-butt welding & & $\times$ & $\times$ \\
\hline Friction welding & $\times$ & $\times$ & \\
\hline Ultrasonic welding & & $\times$ & $\times$ \\
\hline HF welding & & $\times$ & $\times$ \\
\hline Brazing & & $\times$ & \\
\hline Adhesion bonding & & $\times$ & $\times$ \\
\hline Mechanical joining & $\times$ & $\times$ & \\
\hline
\end{tabular}

technological sector, closely integrated into the total process of production.

The main structural materials for welded structures are steel (93-95\%), aluminium, titanium and other non-ferrous metals and plastics (5-7 \% in total), therefore, the development of steel production industry is one of the most main factors defining the state and dynamics of development of welding production not only today, but also in the foreseeable future.

None of other materials has such a combination of strength, ductility, flexibility and cost, as steel. All the produced steel becomes a resource with unlimited cycle of use and can be remelted.

In the world production of steel more than 4 million employees are engaged and another 4 million - in related industries. Steel production industry is the second one in the world as to the energy consumption in spite of the fact that the power intensity of its production over the recent

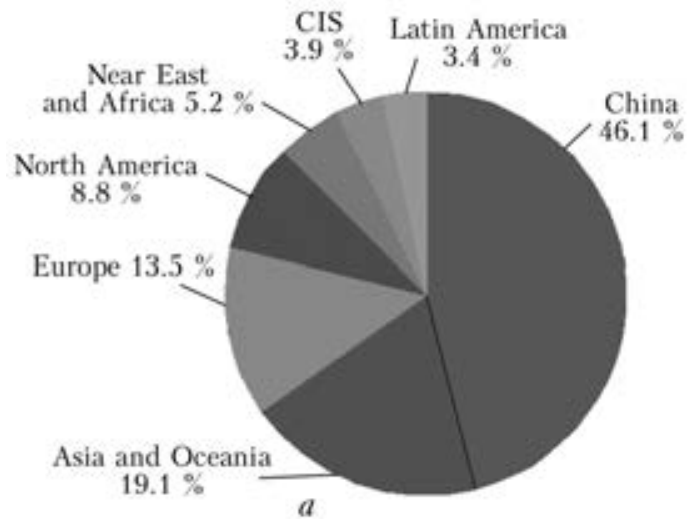

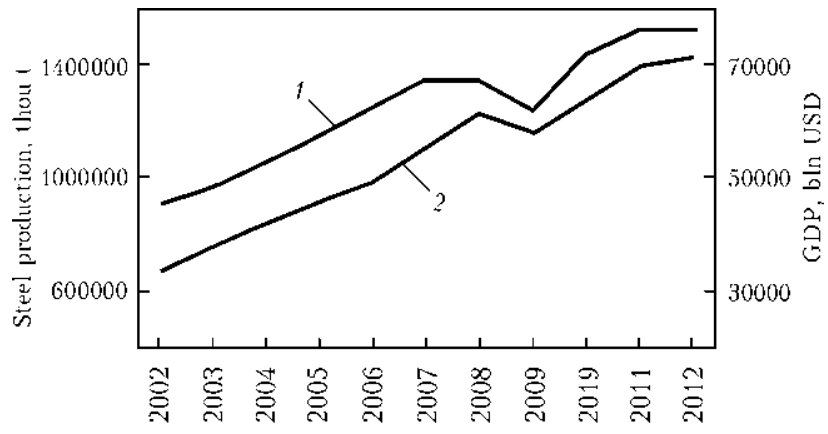

Figure 1. Dynamics of the world indicators of steel production(1) and GDP (2)

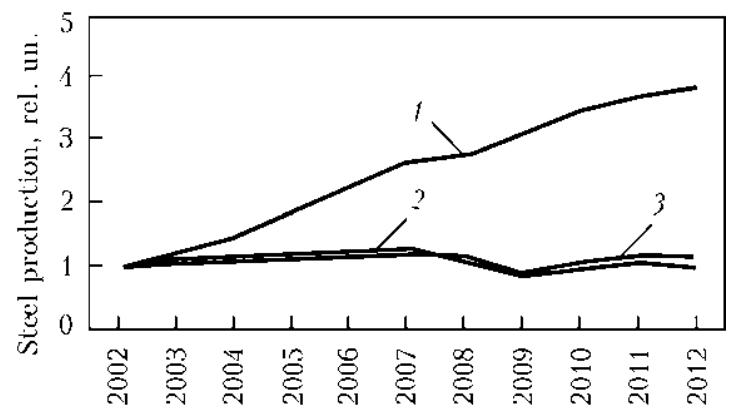

Figure 2. Production of steel in China (1), Ukraine (2) and world (3) (without China) (volume of production in 2002 was taken as unity)

30 years reduced by $50 \%$. It is the mover, which provides the progress of the world industry, and the industry indicators reflect the global economic situation $[4,5]$. Figure 1 shows the close interrelation between the world production of steel, steel rolled metal and GDP. During the recent decade the world volume of steel production was increased by 1.7 times and GDP - by more than 2 times. On average, it is necessary to produce $2 \mathrm{~kg}$ of steel for each 100 USD of GDP increment.

In 2012, according to data of the World Steel Association (WSA), the steel consumption in the world was amounted to $218 \mathrm{~kg}$ per one person, including, kg: China -500 , EU -340 , Russia - 330, the USA - 310, Ukraine - 160, Africa - 30 .

Since 1996 China is the world leader in steel production. In 2012 its share was $46 \%$ (731 million tons) of the world volume. The second place

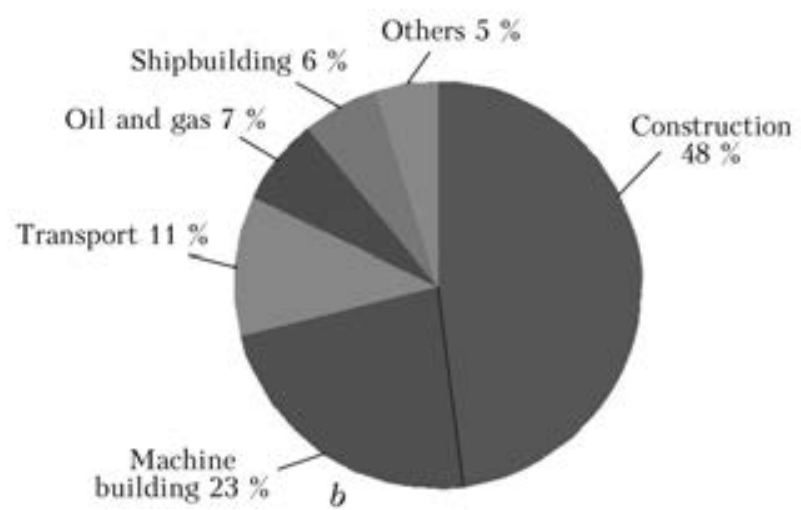

Figure 3. Distribution of world volume of steel consumption by regions $(a)$ and industry branches $(b)$ in 2012 


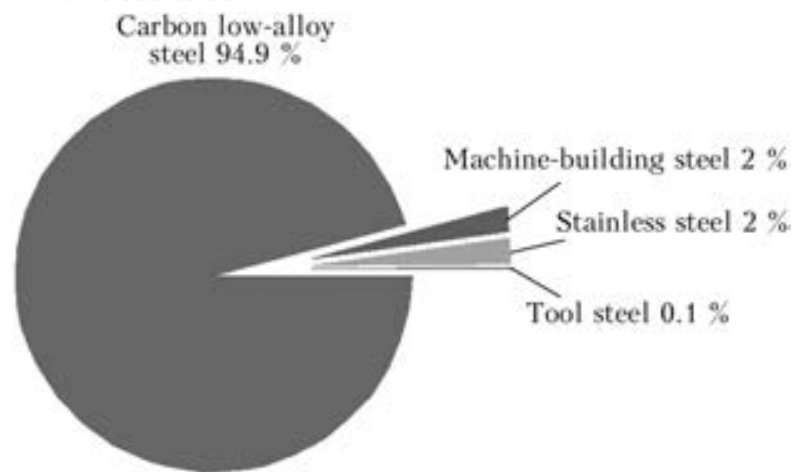

Figure 4. Structure of consumption of rolled metal in 2012 is occupied by Japan, the third one - by the USA. Ukraine in 2012 decreased the steel production by 2.4 million tons as compared to 2011 and lowered in two positions in the rating of the largest producers, occupying 10th position with an indicator of 32.9 million tons [6].

Figure 2 shows the dynamics of growth of steel production in China, Ukraine and world (without China) as compared with 2002.

Tables 2 and Figure 3 show the distribution of the world volume of steel consumption by regions and industry branches.

Structure of consumption of steel rolled metal by steel grades, given in Figure 4, proves that $94.9 \%$ of rolled metal are produced by using carbon and low-carbon steel, the main structural material used in welding.

In spite of the fact that steel production industry encounters a large amount of obstacles, such as excess capacities, volatility of raw materials and energy markets, risks of protectionist policy, steel will remain also in future as one of the most important materials for the advanced economy.

From the estimates of the WSA experts, as well as experts of the International Iron and Steel Institute, the demand for steel will increase up to 2.3 billion tons per year by 2025 . Average annual rates of growth in 2014-2025 will amount

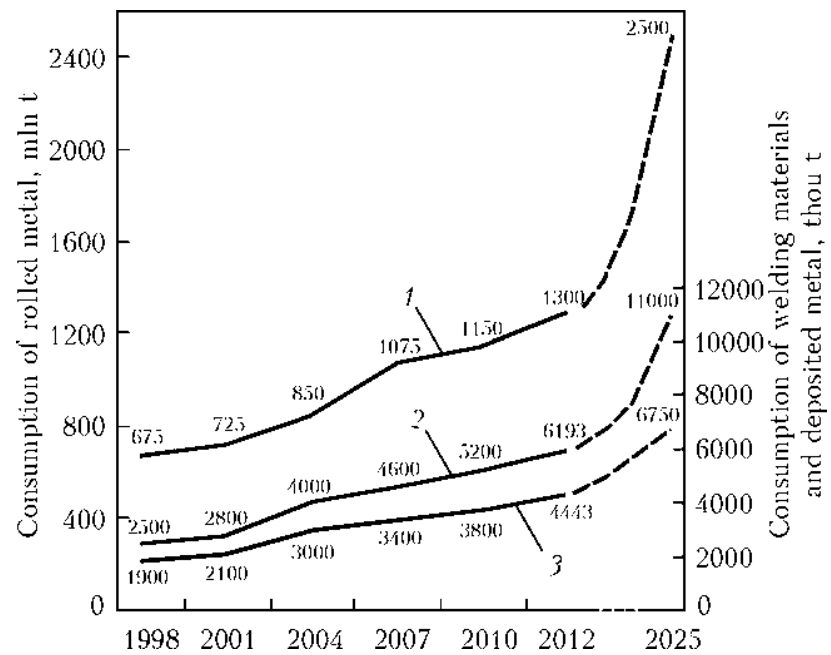

Figure 5. World consumption of rolled metal (1), welding materials (2) and deposited metal (3)
Table 2. Distribution of steel consumption by industry branches in the world, China and EU (\%)

\begin{tabular}{||l|c|c|c||}
\hline \multicolumn{1}{|c|}{ Industry branch } & World & China & EU \\
\hline Construction & 48 & 50 & 38 \\
\hline Machine building & 23 & 19.2 & 24 \\
\hline Transport & 11 & 7.1 & 12 \\
\hline Shipbuilding & 6 & 4.3 & 2 \\
\hline Oil and gas & 7 & 7.1 & 12 \\
\hline Others & 5 & 7.1 & 8 \\
\hline
\end{tabular}

to $3.7 \%$. The construction sector will have $64 \%$ of steel consumption, automobile industry $17 \%$, manufacture of technological machines and equipment (machine building) - $15 \%$.

By $2025,90 \%$ of expected increase in steel consumption will meet the requirements of the following branches:

- civil building, infrastructural projects in countries with the developing economy $(68 \%$ of growth);

- technological machine building (13\%);

- oil-gas and other pipes (9\%).

The above-given information about the state and prospects of development of steel production industry makes it possible to state that the volumes of welding production in the foreseeable future will grow and, respectively, the market of welding materials will increase.

It can be expected that by 2025 the volumes of consumption of rolled metal can reach 2500 million tons, welding consumables - up to 11 million tons. This statement can be based on data, given in Figure 5, about the world consumption of rolled metal, welding materials and mass of metal being deposited, for 1998-2002, and also above-given data about the growth in demand for steel by 2025 .

The brightest example, confirming the general tendency of relationship between the growth of steel consumption and total economic level of countries, characterized by high rate of GDP growth, is China (see Figure 2), which has during recent years the highest and stable rate of GDP increment $(8-10 \%)$ and occupies the first place in the world as to the volume and rates of steel consumption increment [7]. The share of this country in the world steel consumption increased from $20.1 \%$ in 2002 up to $46 \%$ in 2012 .

The EU countries can be given as the second example, the steel consumption increment of which is $1-3 \%$. Such moderate development of consumer's market of steel corresponds to the moderate growth of GDP in these countries, 2$3 \%$ per year on average.

In the world scientific and technical literature two conceptions are sometimes confused: «welding materials» (consumables) and «materials for welding» (suppliers), that leads to misunderstandings in comparison of statistic indicators. 


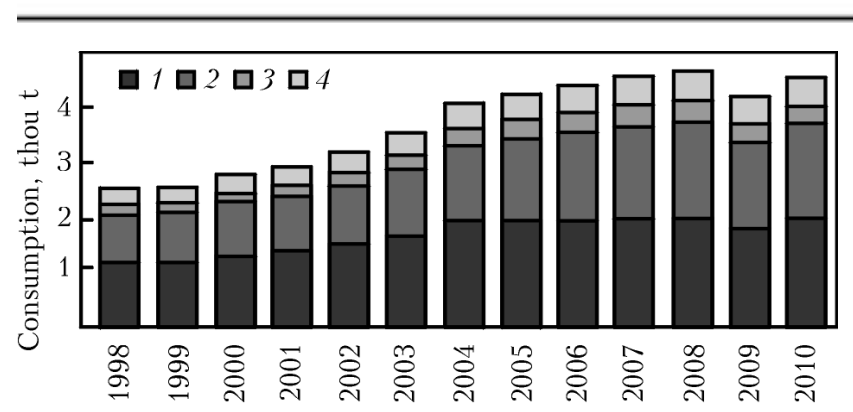

Figure 6. Dynamics of consumption by main types of welding materials: 1 - electrodes; 2 - solid wire; 3 - wire for submerged arc welding; 4 - flux-cored wire

The first conception refers to materials, the most part of which transfers in the process of welding to the composition of weld metal (for arc welding these are solid and flux-cored wires, coated and other consumable electrodes, fluxes), and the second one refers to shielding active and inert gases and other materials, including auxiliary ones, which take part in fulfillment of welding processes. It is a disputable question whether the welding flux is referred to welding materials, but it is considered so in practice. Therefore, we shall use further this interpretation of the term «welding materials», though in some countries the national statistics means namely the «materials for welding», that it is necessary to take into account at international comparisons of appropriate indicators.

In cost volume of the world market of welding industry from the estimation of specialists of ESAB company, the welding materials amounted to $70 \%$ in 1996 , welding equipment - to $30 \%$. By 2006 the ratio of these indicators was, respectively, 45 and $55 \%$. At the present time, it can be considered that the cost volume of the world market of welding materials is about a half of all the volume of welding industry market.

Figures 6 and 7 give the data of ESAB about the volumes of consumption according to main types of welding materials and regions [8, 9].

We periodically selectively compare our data with data of ESAB and Japanese data, published annually in «The Japan Welding News For The World» $[10,11]$ to be convinced in their validity.

The data of ESAB are close to the greater degree to those results, which we obtain in the course of our investigations. We can say also the same about the Japanese data (Table 3 and Figure 8). The advantage of the latter consists in the wider covering of regions and, the most important, in regularity and timeliness of their publication.

The world volume of consumption of welding materials, which amounted to 5946 thous tons in 2011, was increased by $4.2 \%$ and reached 6193 thous tons in 2012. The growth of world volume of consumption of welding materials was determined by the rates of development of welding production of China, much surpassing in this aspect the rest regions. In 2012 China had $51.7 \%$ of all the world consumption of welding materials

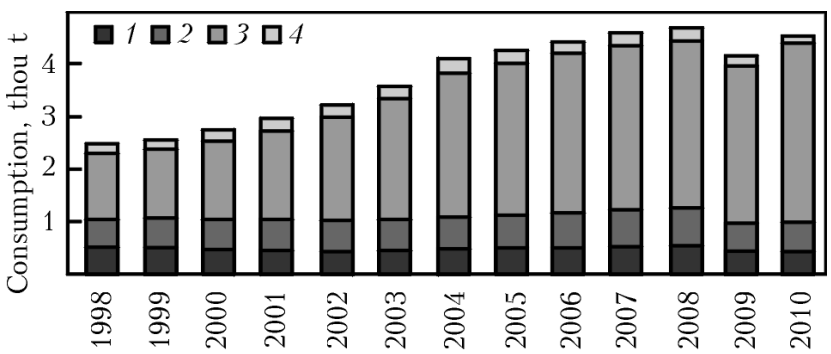

Figure 7. Dynamics of consumption of welding materials by main regions: 1 - North America; 2 - Europe; 3 Asia; 4 - other regions

(3200 thous tons). Far behind were countries of EU: $8.9 \%$ (550 thous tons), and North America (the USA, Canada, Mexico): 6.9\% (430 thous tons).

From 300 to 200 thous tons of welding materials per year are consumed by Japan (283 thous tons), ASEAN (280 thous tons), India (270 thous tons), Korea (240 thous tons), CIS countries (230 thous tons), Latin America (210 thous tons), the Near and Middle East (190 thous tons), Africa (150 thous tons). This list is finalized by the regions of Taiwan (80 thous tons) and other smaller countries with total consumption of 70 thous tons.

The presence of valid and full information about the volumes of consumption of welding materials allows defining the generic structure of methods of arc fusion welding used in the world, regions and in definite country. Usually, as a criterion the mass of deposited metal is used, by means of which a percent share of manual arc welding with covered electrodes (MAW), shielded-gas solid wire welding $\left(\mathrm{CO}_{2}\right)$, fluxcored wire welding (FCW) and automatic submerged arc welding (ASAW) is determined.

Since its foundation in 1965 the PWI Department of Economic Research is carrying out the continuous research of technological structure of

Table 3. Consumption of welding materials in the world, regions, countries [10, 11]

\begin{tabular}{||c|c|c||}
\hline \multirow{2}{*}{\multicolumn{1}{c|}{ Country, region }} & \multicolumn{2}{c|}{$\begin{array}{c}\text { Consumption of welding materials, } \\
\text { thou t }\end{array}$} \\
\cline { 2 - 3 } & 2011 & 2012 \\
\hline World & 5945.6 & 6193 \\
\hline China & 3000 & 3200 \\
\hline EU & 570 & 550 \\
\hline North America & 430 & 430 \\
\hline Japan & 285 & 283 \\
\hline India & 260 & 270 \\
\hline Korea & 230 & 240 \\
\hline Russia, CIS & 220 & 230 \\
\hline \multicolumn{1}{|c|}{ including Ukraine } & 69 & 63 \\
\hline Latin America & 210 & 220 \\
\hline Near and Middle East & 180 & 190 \\
\hline Africa & 140 & 150 \\
\hline Taiwan & 80 & 80 \\
\hline ASEAN & 270 & 280 \\
\hline Others & 70 & 70 \\
\hline \hline
\end{tabular}




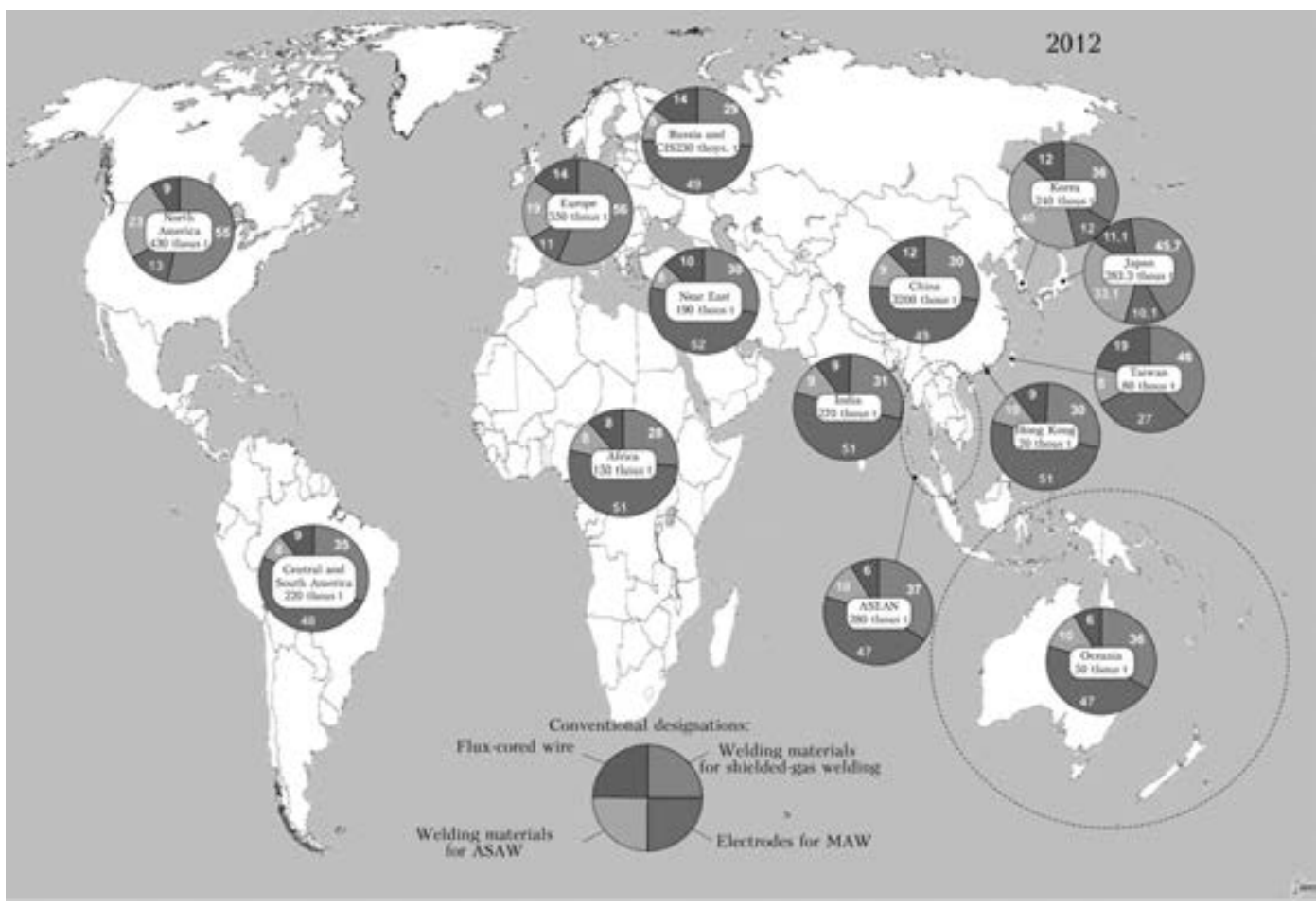

Figure 8. Consumption of welding materials in the world and regions in 2012

arc welding methods in a number of countries, the results of which are given in Table 4 and Figure 9.

The presence of the most complete Japanese data about the world and regional consumption of welding materials (see Figure 8) allowed defining the structure of application of arc welding methods in leading countries, regions and in the world as a whole (Table 5).

Application of data of «The Japan News For The World» for 2012 (see Table 5) shows that they are quite accurately integrated into dynamics of indicators of the PWI data, that proves the rather high degree of validity of information of both sources.
Information, given in Figure 9, confirms that the MAW share, amounting to $80-90 \%$ in leading countries in 1965, was twice decreased for 25 years and was at the level of 35-45\% in 1990. Super optimists of the technical progress in welding production insisted at that period that the next 25 years the MAW share would be equal to zero or a little higher. We considered in our predictions that this method of welding would have the right for existence in the foreseeable future and its share would be about $20 \%$. As we see, not only super optimists and also we were mistaken, because today the MAW share in Japan is $7.3 \%$, in EU $-8.9 \%$, in the South Korea $9.6 \%$ and in the North America (the USA, Can-

Table 4. Technological structure of methods of arc welding in the world (\% by deposited metal)

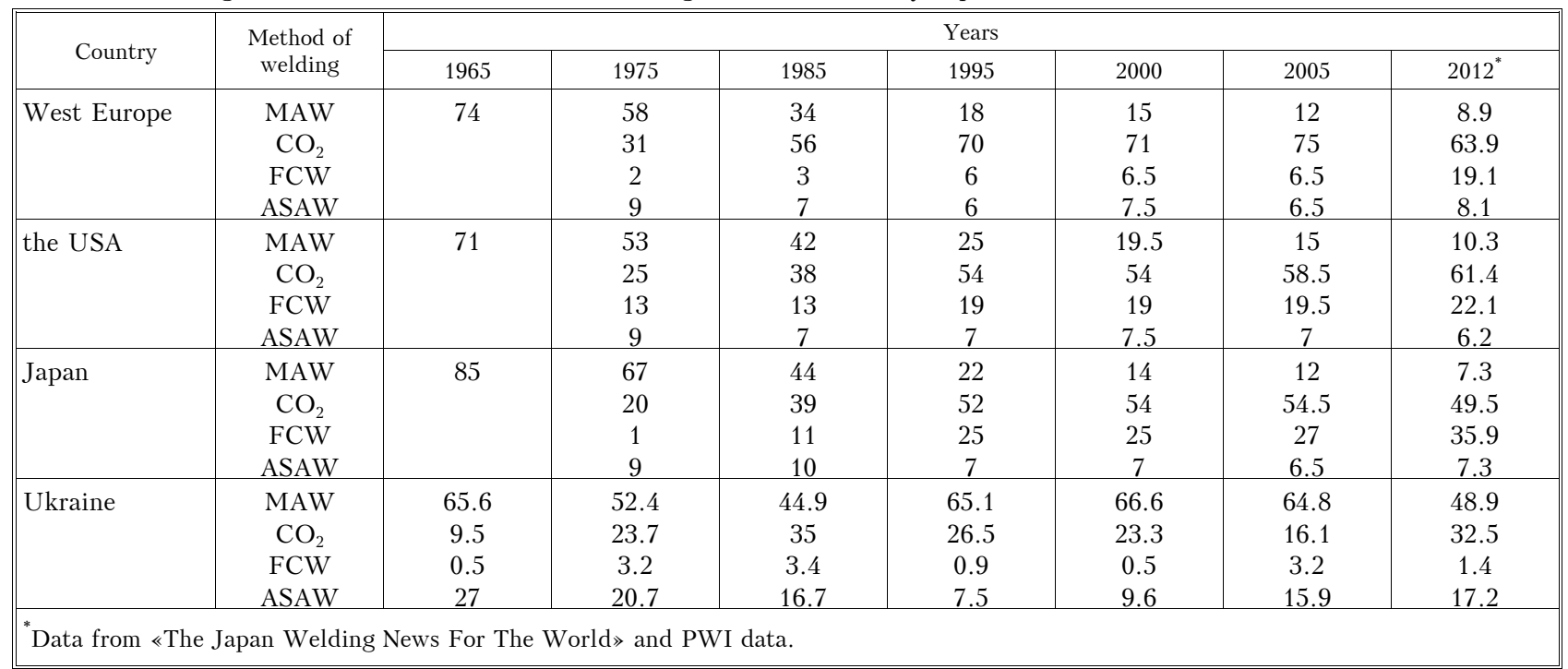




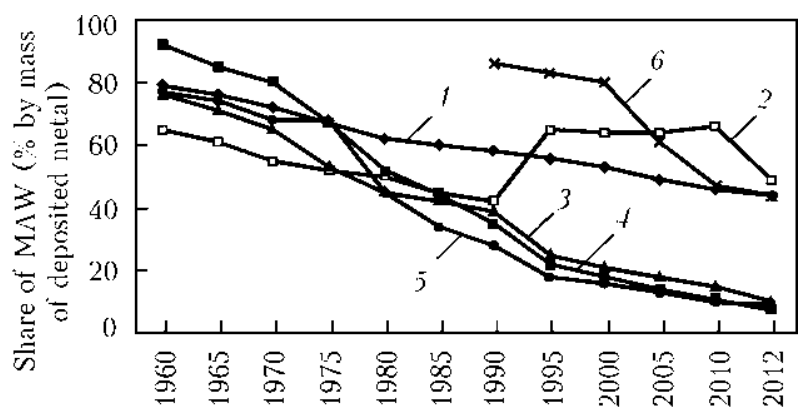

Figure 9. Share of MAW in the world: 1 - Russia; $2-$ Ukraine; 3 - USA; 4 - Japan; 5 - West Europe; 6 China (2012 - from data of «The Japan Welding News For The World» and PWI)

ada and Mexico) - $10.3 \%$. As a whole, the MAW share in the world is continuously decreased and amounted to $33.7 \%$ in 2012, mainly due to China ( $47.3 \%)$, India ( $45 \%$ ), CIS ( $44 \%$ ) and the rest countries, where it is $22-52 \%$.

The share of shielded-gas welding as a whole in the world is amounted to $44 \%$. Leaders in application of this method of welding are EU $(63.9 \%)$, the USA $(61.4 \%)$, Taiwan $(54.8 \%)$ and Japan (49.5\%). Leaders in FCW application are the South Korea (40\%), Japan $(35.9 \%)$ and the USA $(22.1 \%)$. As a whole, the FCW in the world amounted to $14 \%$ in 2012 .

The ASAW, which amounts only to $7.9 \%$ of deposited metal in welding in the world as a whole, is mostly widely used in Ukraine (17.2\%), Russia (10.3\%), China (8.7\%) and in EU $(8.1 \%)$. Over the recent 40 years the ASAW share is almost stable, its fluctuations are as follows: in EU from 6 up to $8.1 \%$; in the USA from 9 to $6.2 \%$; in Japan from 9 to $7.3 \%$; in Ukraine from 20.7 to $17.2 \%$.

In conclusion, it can be noted that welding is the basic technology in many branches of industry and construction. The industrialized countries are characterized by a rather stable dynamics of development of welding production and welding market, which is defined by a stable growth of consumption of structural materials and widening of their assortment, as well as appearance of the new challenging materials, technologies and equipment for welding and related processes at the welding market.

Economical-statistic information about stateof-the-art and prospects of development of the world production and consumption of steel, the main structural material in manufacture of welded metal structures, as well as the dynamics of the world market of welding materials makes it possible to prove that the volumes of the world welding production will grow in the nearest future. Accordingly, the demand for welding materials will grow in spite of temporary crisis phenomena in separate regional markets.

The level of mechanization and automation of welding jobs, which is mainly defined by the
Table 5. Structure of methods of arc welding in the world, regions and countries in 2012 (\% by mass of deposited metal)

\begin{tabular}{||c|c|c|c|c|}
\hline \multirow{2}{*}{ Country } & \multicolumn{4}{c|}{ Method of welding } \\
\cline { 2 - 5 } & MAW & $\mathrm{CO}_{2}$ & FCW & ASAW \\
\hline World & 33.7 & 44.4 & 14 & 7.9 \\
\hline China & 43.7 & 38.4 & 9.3 & 8.7 \\
\hline EU & 8.9 & 63.9 & 19.1 & 8.1 \\
\hline North America & 10.3 & 61.4 & 22.1 & 6.2 \\
\hline Japan & 7.3 & 49.5 & 35.9 & 7.3 \\
\hline India & 45 & 39.4 & 9.2 & 6.5 \\
\hline Korea & 9.6 & 43 & 40 & 7.5 \\
\hline Russia, CIS & 44 & 38.7 & 7.1 & 10.3 \\
\hline Ukraine & 48.9 & 32.5 & 1.4 & 17.2 \\
\hline Latin America & 41.8 & 30.9 & 8 & 6.4 \\
\hline Near and Middle East & 46.5 & 38.5 & 8.2 & 7.3 \\
\hline Africa & 51.2 & 36.2 & 7.1 & 5.9 \\
\hline Taiwan & 21.6 & 54.8 & 18.8 & 5.2 \\
\hline ASEAN & 40.3 & 45.8 & 10.1 & 4.2 \\
\hline Others & 44.4 & 42.5 & 7.7 & 6.8 \\
\hline
\end{tabular}

volume of application of manual arc welding, is continuously increased by reduction of its share and growth of mass of deposited metal in use of semiautomatic and automatic welding in shielding gases and also by the flux-cored wire.

1. Bernadsky, V.N., Mazur, A.A. (1999) State-of-the-art and prospects of world welding market. Avtomatich. Svarka, 11, 49-55.

2. Bernadsky, V.N., Makovetskaya, O.K. (2004) About contribution of welding to economics of the USA. Ibid., 3, 32-38.

3. Bernadsky, V.N., Makovetskaya O.K., Mazur, A.A. (2008) Welding production and market of welding technique in modern economics. In: Proc. of 7th Int. Symp. on Welding and Related Technologies (Minsk, 26 March 2008), 5-9.

4. World Steel Association. Steel Statistical Yearbook 2013. http://www.worldsteel.org/dms/internetDocumentList / statistics-archive / yearbook-archive Steel-Statistical-Yearbook-2013/document/SteelStatistical-Yearbook-2012.pdf

5. SVESTA-2010. http://paton.kiev.ua/images/stories/svesta / pdf / swesta-2010.pdf

6. World Steel Association. World steel in figures 2014. http: / / www. worldsteel.org/dms / internetDocume ntList / bookshop / World-Steel-in-Figures-2014/doc ument/World \%20Steel \%20in \%20Figures \%202014 $\% 20$ Final.pdf

7. Ma Pin. Investigations of market medium of welding production technologies: world tendencies and experience of China. http:/ old.nuwm.rv.ua/metods $/ \mathrm{asp} / \mathrm{vd} / \mathrm{v} 39 \mathrm{ek} 24$.doc

8. Pekkari, B. (2006) The welding world in changing. Lume sudarii, 2, 3-12.

9. Middeldorf, K., fon Hofe, D. (2009) Tendencies in development of technologies for material joining. Mir Tekhniki i Tekhnologij, 11, 12-16.

10. (2012) Worldwide demand for welding consumables. The Japan Welding News For The World, Spring, $16(59), 5$

11. (2013) Worldwide demand for welding consumables. Ibid., $17(63), 6$. 